mending, among other things, a doubling of expenditure on oceanographic research (see Nature, 211, 446; 1966). Although the committee says that the existence of the two new bodies will help to implement the policies it now commends, what it has to say would undoubtedly have been more influential a year ago.

Although the report is principally concerned with an attempt to describe the ways in which oceanographic research can be with advantage increased, it will be read with most attention for what it has to say about the principles on which decisions should be made for investing new funds. The committee seems to be dissatisfied with existing machinery for allocating resources, and writes of the way in which proposals for research are sometimes subjected to "reviews of previous reviews by the same reviewing bodies". It pleads for a distinction between "discipline oriented activities" and "mission oriented activities".

\begin{tabular}{|c|c|c|c|}
\hline \multicolumn{4}{|c|}{$\begin{array}{l}\text { U.S. FEDERAL EXPENDITURE ON OCEANOGRAPHY } \\
\text { (millions of dollars) }\end{array}$} \\
\hline & $\begin{array}{c}\text { Department } \\
\text { of } \\
\text { Defense }\end{array}$ & $\begin{array}{c}\text { National } \\
\text { Science } \\
\text { Foundation }\end{array}$ & $\begin{array}{c}\text { Total } \\
\text { (all } \\
\text { agencies) }\end{array}$ \\
\hline 1958 & $9 \cdot 1$ & $1 \cdot 5$ & $21 \cdot 3$ \\
\hline 1961 & $31 \cdot 6$ & $7 \cdot 9$ & $62 \cdot 1$ \\
\hline 1964 & $54 \cdot 6$ & $19 \cdot 6$ & $123 \cdot 1$ \\
\hline 1967 & $114 \cdot 9$ & $28 \cdot 5$ & $217 \cdot 5$ \\
\hline
\end{tabular}

The first category of research projects is said to include those whose object is to "increase understanding of ocean science as a field of knowledge", and for which the National Science Foundation should be the principal source of funds. (The committee recognizes that agencies such as the Office of Naval Research have played an influential part in supporting basic research in oceanography.) Among the "mission-oriented" projects the committee distinguishes some which are expected to have "near-term payoffs" and those which promise more distant results. It is afraid that longterm projects will be neglected for the sake of quick returns, and asks grant-giving bodies to keep to some more or less constant ratio of activity. In the same spirit, the committee exhorts the independent grantgiving agencies-the National Science Foundation and the Smithsonian Institute-to recognize that practically oriented research should be founded on a sufficient basis of "discipline oriented research". Further restraints on the pattern of spending are imposed by remembering, for example, that a 600 ton research vessel will require that $\$ 1.5$ million a year should be spent in the shore facilities to which the oceanographers return after their spells at sea.

\section{Government Social Survey}

THE British Government Social Survey is to become an independent body responsible to the Treasury on April 1,1967 . Since it was set up in 1941, the survey has been part of the Central Office of Information, originally the Ministry of Information. In 1965 the report of the Committee on Social Studies under Lord Heyworth recommended that the survey should be separated from the COI because of the unavoidable weaknesses of administration. The committee considered that the services which the survey could provide were often inadequately understood by government departments, and that studies being carried out for different departments could in many cases be combined. There was also no provision in the organization of the survey for advance planning to meet the needs of future government policy.

It is hoped that the reorganization will make it possible for the survey to take a more active part in the training of research workers in the social sciences. With an annual budget of about $£ 400,000$, the survey carries out a third of all government research in the social sciences. It is to have a new controller, $\mathrm{Mr}$. T. D. Kingdom, formerly an under secretary at the Ministry of Social Security, who will report to an interdepartmental committee composed of people from the main user departments and from the Treasury.

\section{Some Cheer from Florence}

The Botanical Institute of Florence seems to have survived the floods of November 1966 with less damage than was at first expected. The director of the institute, Dr. Eleanora Francini Corti, says that the institute and the garden were flooded, the ground floor to a depth of $70 \mathrm{~cm}$. Nevertheless the great herbaria, which are the most important collections at the institute and which were kept on the first and second floors, were quite undamaged. The underground archives were less well protected, but it seems that the inks of the oldest manuscripts have survived their submersion without damage. The newer volumes survived less well, partly because of the quality of the paper from which they were made. Stocks of the botanical journals published from Florence have been seriously damaged. As a whole, however, it seems that the flood waters which invaded the institute were not contaminated with the petroleum products which proved to be extremely damaging elsewhere in the city.

\section{Science Spending in New Zealand}

ThE New Zealand government has been doubling its expenditure on science every seven or eight years for the last three decades according to figures compiled by the New Zealand National Research Advisory Council and now published by the New Zealand Department of Scientific and Industrial Research, Wellington (Scientific Research in New Zealand-Government Expenditure and Manpower 1926-1966, 5s.). Even so, the total expenditure in New Zealand on scientific research by the government amounted to just under f6 million in 1966. The Department of Scientific and Industrial Research is the largest consumer of funds ( $£ 1.7$ million), and agriculture takes more than a fifth of the total - a proportion which has been declining steadily over the years since the war, when more than a third of all public expenditure on research was spent on agriculture. These figures are reflected in the pattern of employment. Public service in New Zealand employs just under 1,000 people on research, with 562 of them in the Department of Scientific and Industrial Research, 255 in agriculture, and mere handfuls elsewhere except in forestry.

\section{Calouste Gulbenkian Foundation}

DuRING 1966 the Calouste Gulbenkian Foundation gave away $£ 4,635,000$ in the form of grants, $£ 532,432$ of it in Britain and the British Commonwealth. In the Commonwealth the interest of the Foundation is mainly in the arts, and about half the money spent 